\title{
Do Discretionary Accruals Help Distinguish between Internal Control Weaknesses and Fraud?
}

\author{
Mary Jane Lenard ${ }^{1}$, Bing $\mathrm{Yu}^{1} \&$ E. Anne York ${ }^{1}$ \\ ${ }^{1}$ School of Business, Meredith College, Raleigh, North Carolina, USA \\ Correspondence: Mary Jane Lenard, School of Business, Meredith College, Raleigh, NC 27607, USA. Tel: \\ 1-919-760-8488. E-mail: lenardmj@meredith.edu
}

Received: October 6, 2013

Accepted: October 17, 2013

Online Published: November 22, 2013

doi: 10.5539/ibr.v6n12p84

URL: http://dx.doi.org/10.5539/ibr.v6n12p84

\begin{abstract}
This paper extends the investigation of the effectiveness of discretionary accruals in detecting fraud and evaluating internal control weaknesses. Our sample is divided into four subsamples: healthy firms, firms that experienced internal control weaknesses, firms that committed financial reporting fraud, and firms that committed fraud by violating stock options reporting rules. We develop a logistic regression model with discretionary accruals variables and other financial variables, to identify the characteristics of firms that have internal control weaknesses and the two different types of financial statement fraud. The model is $79.1 \%$ accurate in distinguishing firms with internal control weaknesses from firms with financial reporting fraud; $71.6 \%$ accurate in distinguishing firms with internal control weaknesses from firms with options reporting; and $87.5 \%$ accurate in distinguishing firms with financial reporting fraud from firms with options reporting fraud. These models are helpful to the auditor for assessing the risk of various types of fraud.
\end{abstract}

Keywords: fraudulent financial reporting, discretionary accruals, audit risk, internal control

\section{Introduction}

As part of the Sarbanes-Oxley (SOX) Act of 2002, all SEC registrants must comply with Section 404, which requires identification and public disclosure of internal control weaknesses. The requirement to identify deficiencies in internal control is intended to provide further assurance of the quality of financial statements, along with the financial statement audit. Yet internal control weaknesses do not necessarily indicate fraud. A distinction may be made as to whether management intentionally committed fraud, regardless of the strength or weakness of their internal control system. Being able to identify a firm that is committing fraud is an important issue for the auditor.

Because firms that commit fraud may also manage earnings, one way to identify such firms is by examining discretionary accruals. Models of discretionary accruals have been examined in the literature as a way to smooth income, and thus manage earnings (Geiger \& North, 2006; Tucker \& Zarowin, 2006). Recently, studies have investigated the link between the implementation of SOX (2002) and changes in discretionary accruals, as well as the association between weak internal controls and accruals quality (Ashbaugh-Skaife et al., 2008; Chan et al., 2005, Cohen et al., 2005; Doyle et al., 2007; Iliev, 2007; Lai, 2003). In addition, discretionary accruals models have been used to detect cases of fraud and restated earnings (Jones et al., 2008).

In this paper, we extend the investigation of the ability of discretionary accruals models to predict fraud. Specifically, we look at the ability of discretionary accruals and fraud models to recognize two specific types of financial reporting fraud and companies that have internal control weaknesses but are not fraudulent. We identified companies that committed financial reporting fraud, and companies that committed fraud due to violations in reporting of stock options. We then obtained a sample of firms that had internal control weaknesses. We use a model that employs discretionary accruals and other financial variables to distinguish among the firms with these different financial reporting problems, and to separate them from healthy firms. Our results extend the literature that has been established to observe the ability of discretionary accruals to detect fraudulent earnings statements. Our findings have important implications for auditors in assessing fraud risk and for individuals in corporate governance who are charged with overseeing the quality of financial reporting.

The remainder of this paper is organized as follows. Section 2 provides a literature review related to discretionary accruals and models to detect financial reporting fraud. Section 3 gives our statement of hypotheses 
and Section 4 describes the methodology for performing our analysis. We describe the results of our analysis in section 5 and we offer some concluding remarks in Section 6.

\section{Literature Review}

\subsection{Earnings Management}

Jones (1991) used a discretionary accruals model to test whether firms that would benefit from import relief attempted to decrease earnings through earnings management and therefore avoid import relief investigations. Her model focused on the discretionary portion of total accruals in order to capture earnings management. Based on a model by DeAngelo (1986), the "abnormal" total accruals are defined as the difference between current total accruals and normal total accruals. This abnormal accrual amount can then be separated into discretionary and nondiscretionary accruals. The assumption is that the average change in nondiscretionary accruals is approximately zero, so that a change in total accruals primarily reflects a change in discretionary accruals (Jones, 1991).

Tucker and Zarowin (2006) studied income smoothing by reasoning that there is an underlying pre-managed income series and that managers then use discretionary accruals to smooth reported income. They measured income smoothing as the negative correlation of a firm's change in discretionary accruals with its change in pre-managed income. A more negative correlation indicated more income smoothing (Tucker \& Zarowin, 2006). Other authors (Aboody \& Kasznik, 2000; Bartov et al., 2002; Bartov \& Mohanran, 2004) found indications of companies' use of earnings management in order to meet earnings expectations. Iliev (2007) and Lai (2003) found that all firms reduced discretionary accruals in the year following the implementation of the Sarbanes-Oxley Act. However, by smoothing income through the use of discretionary accruals, companies with weaker internal control systems may encounter internal control violations.

\subsection{Internal Control Weaknesses and Fraud}

Previous models of fraud detection have examined internal control weaknesses along with examination of financial ratios in companies that committed financial reporting fraud. Lenard and Alam (2004) and Lenard et al. (2007) developed successful fraud prediction models that included a variable as a proxy for the strength or weakness of a company's internal controls. However, firms that report weak internal controls don't necessarily commit fraud. Internal control weaknesses are now part of the reporting process under the Sarbanes-Oxley Act of 2002. Several studies have examined the connection between discretionary accruals and internal control weaknesses reported under Section 404 of the Sarbanes-Oxley Act. Doyle et al. (2007) reported an association between weak internal controls and lower accruals quality. Chan et al. (2005) found mild evidence that there were more positive and absolute discretionary accruals for firms reporting material internal control weaknesses than for other firms. Firms reporting material internal control weaknesses also had lower return-earnings associations than other firms (Chan et al., 2005). Ashbaugh-Skaife et al. (2008) found that through the reporting of internal control deficiencies under the SOX legislation, those firms reporting deficiencies had lower quality accruals as measured by accrual noise, in addition to significantly larger positive and larger negative abnormal accruals, relative to control firms.

Management may have various reasons to materially overstate earnings, leading to fraud. There may be pressures to camouflage financial distress (Argenti, 1976; Summers \& Sweeney, 1998; Rosner, 2003), desire to meet earnings expectations (Burgstahler \& Dichev, 1997; Bartov et al., 2002; Graham et al., 2005), or desire to maintain high stock prices for compensation benefits and therefore commit fraud through the fraudulent reporting of stock options. Previous studies have found that compensation in the form of stock options gives management incentives to manipulate earnings (Beck, 2003; Cassidy, 2002). Meek et al. (2007) found a possible relationship between $\mathrm{CEO}$ stock option compensation and fraud, implying that earnings management is more likely where stock options are a larger part of CEO compensation.

Recent literature has used discretionary accruals models to detect fraud by examining extreme cases of earnings management. Jones et al. (2008) used the size of the downward earnings restatement following the discovery of the fraud to proxy for the degree of discretion exercised to perpetrate the fraud. They found that accrual estimation errors were associated with the existence and magnitude of fraud and non-fraud restatements.

\section{Hypotheses}

Tucker and Zarowin's (2006) model computes pre-discretionary income $(P D I)$ as net income $(N I)$ minus a discretionary-accruals proxy $(D A P)$. Thus, $P D I$ plus $D A P$ is equal to net income, and if there is lower $P D I$, a higher level of $D A P$ will maintain, or "smooth", net income. The authors found that more, or higher, income smoothing is evident if there is a more negative correlation between $P D I$ and $D A P$. 
In this study, we propose to use a discretionary accruals model and the resulting estimates of total accruals and discretionary accruals, along with financial variables that have been used in fraud detection models, to (1) separate firms with internal control weaknesses from fraud firms, and (2) distinguish between firms that commit fraud due to revenue recognition and asset misappropriation from firms that commit fraud in reporting stock options. Our first research hypothesis is:

H1: There will be a significant difference in discretionary accruals among healthy firms, types of fraud firms, and firms that have internal control weaknesses.

Successful results from this hypothesis will provide an additional method for distinguishing between problem firms and fraudulent firms when examining internal controls. Therefore our second research hypothesis is:

H2: A discretionary accruals variable included in a fraud detection model will be significant in distinguishing among healthy firms, types of fraud firms, and firms that have internal control weaknesses.

In separating the different types of fraud, we propose to determine the explanatory power of the discretionary accruals variable in helping to indicate when the use of discretionary accruals goes beyond earnings management and becomes a fraudulent event. Acceptance of this research hypothesis would also signify the ability of discretionary accruals variables, along with other prominent financial variables, to indicate differences in the financial structures of firms that commit different types of fraud, and therefore aid in overall fraud detection.

\section{Methodology}

\subsection{Sample}

To identify companies that committed financial reporting fraud, we searched two sources. We first obtained the 2008 Report on Corporate Fraud from the website of the U.S. Department of Justice (http://www.usdoj.gov/dag/cttf/corporate-fraud2008.pdf). In examining this report, we included cases prosecuted by the DOJ's Criminal division, as well as from the U.S. Attorney's office, which pertained to accounting and financial reporting fraud. There were 31 companies that met this definition. We were able to find data listed on the SEC's Edgar Database for 17 of the companies. The dates of their infractions ranged from 2000 to 2003. We added to this sample by obtaining a list of companies that were subject to litigation for financial statement fraud according to the Lexis-Nexis database during the 1992-2000 time period. This resulted in another 19 companies, for a total of 36 companies in the sample that were subject to financial reporting fraud. After adjusting the sample due to missing data, the final size of this sample came to 32 firms. The total time period for these fraud companies is $1992-2003$.

We then identified a sample of 49 companies that committed financial reporting fraud due to violations in reporting of stock options. The sample consisted of companies that were subject to litigation for violations in reporting of stock options according to the Lexis-Nexis database during the 1997-2007 time period. From the original list of 49 companies, we were able to obtain data for 32 companies.

To obtain a sample of companies with internal control weaknesses, we identified 236 companies that received two or more material weaknesses (which we termed an "adverse" result) in their internal control report, issued under the requirements of section 404 of the Sarbanes-Oxley Act (2002), and reported in Compliance Week 2004 We took a random sample of 36 companies in order to match the size of our datasets. The matching process followed the procedure of previous studies using logistic regression (logit) models with matched samples of experimental and control firms (Chen \& Church, 1992; Hansen, McDonald \& Stice, 1992). We used company data for three years in order to have a cross-sectional model for testing of the accruals models - 2003, the year before the internal control reports that we examined were issued; 2004, the year of the internal control reports, and 2005, the year following the internal control reports. One company did not have sufficient data to include in our analysis, resulting in a final sample for this group of 35 companies.

Finally, we selected a random sample of 36 Fortune 1000 companies in order to have a control group for our sample. We used company data from the years 2003 to 2005 for this sample. As a result, our final numbers for the components of the sample are as follows. There were 36 healthy companies (which we identified as "type 0"), 35 companies with internal control weaknesses (type 1), 32 companies that committed financial reporting fraud (type 2), and 32 companies that committed options reporting fraud (type 3 ).

\subsection{Discretionary Accruals Model}

Tucker and Zarowin (2006) used an income-smoothing model based on Jones (1991) and modified by Kothari et al. (2005). We adopted the same model, as follows:

$$
\text { Acrual }_{\mathrm{t}}=a\left(1 / \text { Assets }_{t-1}\right)+\text { b }_{\text {Sales }}+c P P E_{t}+d R O A_{t}+\mu_{t},
$$


where the total accruals (Accruals) are a function of the change in sales divided by the beginning-of-year total assets ( $\triangle$ Sales); gross property, plant, and equipment $(P P E)$ divided by the beginning-of-year total assets; and return on assets $(R O A)$. Actual Accruals are computed as the difference between net income $(N I)$ and cash flow from operations $(C F O)$. Then the non-discretionary accruals $(N D A P)$ are the fitted values of Equation (1), and discretionary accruals $(D A P)$ are the deviations of actual accruals from NDAP $(D A P=N D A P-A c c r u a l s)$. The pre-discretionary income $(P D I)$ is calculated as net income $(N I)$ minus discretionary accruals $(D A P)$, or $P D I=$ $N I-D A P$ (Tucker \& Zarowin, 2006).

We measured income smoothing as the correlation between the change in discretionary accruals and the change in pre-discretionary income, or Corr $(\triangle D A P, \triangle P D I)$, using three years of data for each firm. For the fraud companies, we used data for the fraud year and two previous years. Using the reasoning presented by Tucker and Zarowin (2006), this measure assumes that there is an underlying pre-managed income series and that managers use discretionary accruals to smooth reported income. Higher, or more, income smoothing is evident in a more negative correlation between $\triangle D A P$ and $\triangle P D I$. We then performed t-tests comparing the variables for each of the groups.

\subsection{Fraud Model}

We used a logistic regression model to see if it was possible to classify firms into their particular group. The financial variables were chosen based on an examination of the literature that investigates fraud detection models Persons (1995) used a logistic regression model to successfully identify factors associated with fraudulent financial reporting. Persons' model used ratios for financial leverage and profitability, as well as ratios that reflect asset composition, including current assets divided by total assets. Success rates in terms of prediction accuracy for Persons' study were as high as $97 \%$. Further, a recent study by Liou (2008) found that variables describing the company's operations were also significant in detecting fraud, along with variables reflecting liquidity, leverage and profitability. In additional literature that examined fraud, Grove and Basilico (2008) studied key ratios and found that ratios which considered sales growth and changes in accruals were more likely to detect situations of fraudulent financial reporting. We included each of these types of ratios in our fraud detection model, formulating the model as follows:

$$
\text { Fraud }=\mathrm{a}+\mathrm{b} T L T A+\mathrm{c} C A T A+\mathrm{d} S A T A+\mathrm{e} A C C T A+\mathrm{f} D A P+\mathrm{g} N I T A+\mu_{\mathrm{t}}
$$

where Fraud is a function of financial leverage, depicted by total liabilities / total assets (TLTA); asset composition, computed as current assets / total assets (CATA); an operations variable, described as sales / total assets $(S A T A)$; the influence of accruals, shown by accruals / total assets (ACCTA) and discretionary accruals / total assets $(D A P)$; and a profitability variable, net income / total assets (NITA).

\section{Results}

\subsection{Discretionary Accruals Model and T-Tests}

Table 1. Estimation of discretionary accruals

\begin{tabular}{cccccc}
\hline Statistics & 1/Assets & $\Delta$ Sales & PPE & ROA & Adj R-sq \\
\hline Mean & -0.039 & -0.121 & -0.071 & 0.388 & 0.463 \\
Standard Deviation & 0.469 & 0.029 & 0.044 & 0.183 & 0.120 \\
Median & 0.202 & -0.115 & -0.089 & 0.306 & 0.433 \\
Minimum & -0.580 & -0.152 & -0.102 & 0.260 & 0.362 \\
Maximum & 0.260 & -0.096 & -0.021 & 0.598 & 0.595 \\
\hline
\end{tabular}

Description: The estimation model is Accruals $s_{t}=\beta_{1}\left(1 /\right.$ Assets $\left._{t-1}\right)+\beta_{2} \Delta$ Sales $_{t}+\beta_{3} P P_{t}+\beta_{4} R A_{t}+\mu_{t}$. Variables are calculated as Accruals $t_{t}=$ Income before extraordinary items - cash flow from operations; Assets $_{\mathrm{t}-1}=$ the total assets at the beginning of fiscal year $t$; Sales $\mathrm{s}_{\mathrm{t}}=$ the $_{\text {change }}$ in sales from fiscal years $t-1$ to $t$; PPEt $=$ the gross property, plant, and equipment at the end of fiscal year $t$; $\mathrm{ROA}_{t}=$ return on assets. All variables are scaled by the beginning of fiscal year total assets.

Table 1 presents the summary statistics of the estimated coefficients and adjusted $\mathrm{R}^{2}$ of firm-year regressions from 2003 to 2005, using our model specified in equation (1).

Table 2 shows the results of t-test comparisons among the different groups. For the type 0 (healthy) firms vs. type 1 (weak internal controls) firms, we examined the year 2004, which was the year the type " 1 " firms 
received the unfavorable IC report. In this year, compared to healthy companies, Net income / total assets (NITA) was significantly lower for type 1 firms, as were total Accruals, discretionary accruals $(D A P)$, pre-discretionary income $(P D I)$, and firm size as measured by the log of total assets $(L N T A)$. This result corresponds to previous research that indicates that firms with weak internal controls reduced their discretionary accruals after the implementation of the Sarbanes-Oxley Act in 2004.

When comparing the healthy (type 0) firms to the firms that committed financial statement fraud (type 2), discretionary accruals $(D A P)$, net income divided by total assets $(N I T A)$, and size as measured by log of total assets $(L N T A)$ were all significantly higher for the healthy firms. When comparing the healthy (type 0) firms to the firms that committed financial fraud due to improper options reporting (type 3), the type 3 firms had significantly lower total assets $(L N T A)$. The type 3 firms also had significantly lower pre-discretionary income $(P D I)$, significantly lower debt ratio (TLTA), and significantly lower sales to total assets (SATA) than the healthy firms.

When comparing the type 1 (weak internal controls) with the type 2 (financial statement fraud) firms (shown in Table 2, Panel B), the change in discretionary accruals ( $D A P$ ) from the previous year to the adverse internal control report year (type 1), or to the fraud year (type 2), was significantly lower for the fraud companies. Hence, it indicates that in the year of discovery of fraud, firms may adopt more conservative accounting practices. The size of the fraud companies, as measured by the log of total assets (LNTA), was significantly higher than the companies with weak internal controls.

The comparison of type 1 (weak internal controls) to the type 3 firms (companies that committed fraud due to improper options reporting) indicated significantly higher net income to total assets (NITA), discretionary accruals $(D A P)$, current assets to total assets $(C A T A)$ and $\log$ of total assets $(L N T A)$ for the type 3 firms. This indicates that the type 3 firms had more aggressive accounting practices than the firms with internal control weaknesses.

Table 2, Panel C shows the comparison of the two different types of fraud companies (type 2 vs. type 3 ). The firms that committed fraud due to improper options reporting (type 3 firms) had significantly higher discretionary accruals $(D A P)$ and significantly higher current assets to total assets $(C A T A)$ than the firms that committed financial reporting fraud for other reasons. On the other hand, the type 3 firms had lower debt (TLTA) compared to the other fraud firms.

Table 2. Panel A. descriptive statistics for discretionary accruals model; Type 0 (healthy company) vs. Type 1 (internal control weakness), Type 2 (financial statement fraud) and Type 3 (options reporting fraud)

\begin{tabular}{|c|c|c|c|c|}
\hline Variable & Mean - Type 0 & $\begin{array}{c}\text { Mean - Type } 1 \\
\text { (t-value) }\end{array}$ & $\begin{array}{c}\text { Mean - Type } 2 \\
\text { (t-value) }\end{array}$ & $\begin{array}{c}\text { Mean - Type } 3 \\
\text { (t-value) }\end{array}$ \\
\hline \multirow[t]{2}{*}{ Accruals } & -0.052 & -0.092 & -0.020 & -0.077 \\
\hline & & $(1.761)^{*}$ & $(-0.941)$ & $(1.563)$ \\
\hline \multirow[t]{2}{*}{ NITA } & 0.062 & -0.034 & -0.039 & 0.037 \\
\hline & & $(4.269)^{* * *}$ & $(2.242)^{* *}$ & (1.188) \\
\hline \multirow[t]{2}{*}{ DAP } & 0.028 & -0.019 & -0.046 & 0.046 \\
\hline & & $(2.175)^{* *}$ & $(2.569)^{* *}$ & $(-0.852)$ \\
\hline \multirow[t]{2}{*}{ CHG_DAP } & 0.001 & 0.036 & -0.029 & 0.012 \\
\hline & & $(-1.590)$ & $(0.880)$ & $(-0.698)$ \\
\hline \multirow[t]{2}{*}{ PDI } & 0.033 & -0.015 & 0.007 & -0.088 \\
\hline & & $(1.991)^{*}$ & $(0.683)$ & $(2.178)^{*}$ \\
\hline \multirow[t]{2}{*}{ CHG_PDI } & -0.001 & -0.323 & -0.037 & -0.009 \\
\hline & & $(0.992)$ & $(0.773)$ & $(0.406)$ \\
\hline \multirow[t]{2}{*}{ TLTA } & 0.617 & 0.702 & 0.655 & 0.350 \\
\hline & & $(-0.690)$ & $(-0.575)$ & $(6.331)^{* * *}$ \\
\hline CATA & 0.391 & 0.460 & 0.441 & 0.573 \\
\hline
\end{tabular}




\begin{tabular}{lcccc}
\hline & & $(-1.293)$ & $(-0.864)$ & $(-4.160)^{* * *}$ \\
SATA & 1.197 & 1.182 & 1.038 & 0.886 \\
& & $(0.070)$ & $(0.752)$ & $(1.798)^{*}$ \\
LN_TA & \multirow{2}{*}{9.497} & 5.883 & 7.344 & 7.420 \\
& & $(10.185)^{* * *}$ & $(4.529)^{* * *}$ & $(5.641)^{* * *}$ \\
\hline
\end{tabular}

Table 2. Panel B: Type 1 (internal control weakness) vs. Type 2 (financial statement fraud) and Type 3 (options reporting fraud)

\begin{tabular}{|c|c|c|c|}
\hline Variable & Mean - Type 1 & $\begin{array}{c}\text { Mean - Type } 2 \\
\text { (t-value) }\end{array}$ & $\begin{array}{c}\text { Mean - Type } 3 \\
\text { (t-value) }\end{array}$ \\
\hline \multirow[t]{2}{*}{ Accruals } & -0.092 & -0.020 & -0.077 \\
\hline & & $(-1.931)^{*}$ & $(1.563)$ \\
\hline \multirow[t]{2}{*}{ NITA } & -0.034 & -0.039 & 0.037 \\
\hline & & $(0.101)$ & (1.188) \\
\hline \multirow[t]{2}{*}{ DAP } & -0.019 & -0.046 & 0.046 \\
\hline & & $(0.785)$ & $(-0.852)$ \\
\hline \multirow[t]{2}{*}{ CHG_DAP } & 0.036 & -0.029 & 0.012 \\
\hline & & $(1.724)^{*}$ & $(-0.698)$ \\
\hline \multirow[t]{2}{*}{ PDI } & -0.015 & 0.007 & -0.088 \\
\hline & & $(-0.543)$ & $(2.178)^{*}$ \\
\hline \multirow[t]{2}{*}{ CHG_PDI } & -0.323 & -0.037 & -0.009 \\
\hline & & $(-0.836)$ & $(0.406)$ \\
\hline \multirow[t]{2}{*}{ TLTA } & 0.702 & 0.655 & 0.350 \\
\hline & & $(0.344)$ & $(6.331)^{* * *}$ \\
\hline \multirow[t]{2}{*}{ CATA } & 0.460 & 0.441 & 0.573 \\
\hline & & $(0.300)$ & $(-4.160)^{* * *}$ \\
\hline \multirow[t]{2}{*}{ SATA } & 1.182 & 1.038 & 0.886 \\
\hline & & $(0.613)$ & $(1.798)^{*}$ \\
\hline \multirow[t]{2}{*}{ LN_TA } & 5.883 & 7.344 & 7.420 \\
\hline & & $(-2.845)^{* * *}$ & $(-3.691)^{* * *}$ \\
\hline
\end{tabular}

Table 2. Panel C: Type 2 (financial statement fraud) vs. Type 3 (options reporting fraud)

\begin{tabular}{lccc}
\hline Variable & Mean - Type 2 & Mean - Type 3 & T-value \\
\hline Accruals & -0.020 & -0.077 & 1.656 \\
NITA & -0.039 & 0.037 & -1.614 \\
DAP & -0.046 & 0.046 & $-2.833^{* * *}$ \\
CHG_DAP & -0.029 & 0.012 & -1.163 \\
PDI & 0.007 & -0.088 & 0.416 \\
CHG_PDI & -0.037 & -0.009 & -0.580 \\
TLTA & 0.655 & 0.350 & $4.557^{* * *}$ \\
CATA & 0.441 & 0.573 & $-2.313^{* * *}$ \\
\hline
\end{tabular}




\begin{tabular}{llcc}
\hline SATA & 1.038 & 0.886 & 0.777 \\
LN_TA & 7.344 & 7.420 & -0.145 \\
\hline
\end{tabular}

Description: Accruals = actual accruals computed as net income minus cash flow from operations $/$ total assets; NITA = net income $/$ total assets; DAP = discretionary accruals (deviations of actual accruals from non-discretionary accruals); CHG_DAP = change in discretionary

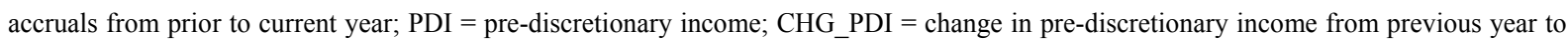
current year; TLTA = total liabilities / total assets; CATA = current assets / total assets; SATA = sales / total assets; LN_TA $=$ log of total assets.

Sample size: $\mathrm{N}=36$ for healthy companies, $\mathrm{N}=35$ for firms reporting internal control weaknesses, $\mathrm{N}=32$ for firms with financial reporting fraud, $\mathrm{N}=32$ for firms with options reporting fraud.

Note: $* * * \mathrm{p} \leq .01, * * \mathrm{p} \leq .05,{ }^{*} \mathrm{p} \leq .10$

Then, as shown in Table 3, we looked at the statistic for the correlation between the change in discretionary accruals (DAP) and the change in pre-discretionary income (PDI). If the correlation is negative and significant, it indicates income smoothing (Tucker \& Zarowin, 2006). We made this comparison for the change from year 1 to year 2, and the change from year 2 to year 3, in each of our data samples. All correlations were negative except for the weak internal control firms from year 2003 to 2004 (year 1 to year 2). This supports the finding above that companies with weaker internal controls had lower discretionary accruals in the year immediately following Sarbanes-Oxley implementation. All of the other types of firms in our sample had a significant negative correlation, indicating income smoothing.

Table 3. Comparison of pearson correlation coefficients between discretionary accruals (DAP) and pre-discretionary income (PDI)

\begin{tabular}{lcc}
\hline & $\begin{array}{c}\text { Change: Year 1 to Year 2 } \\
\text { (Significance) }\end{array}$ & $\begin{array}{c}\text { Change: Year 2 to Year 3 } \\
\text { (Significance) }\end{array}$ \\
\hline Type 0 (Healthy firms) & -0.867 & -0.561 \\
& $(.000)$ & $(.000)$ \\
Type 1 (Internal control weakness) & -0.132 & -0.562 \\
& $(.472)$ & $(.001)$ \\
Type 2 (Financial reporting fraud) & -0.402 & -0.391 \\
& $(.022)$ & $(.027)$ \\
Type 3 (Options reporting fraud) & -0.476 & -0.645 \\
\end{tabular}

\subsection{Logistic Regression Fraud Detection Models}

The results of the logistic regression models and classification accuracies are given in Table 4 . When the type 0 (healthy) firms are compared to the other firms (Table 4, Panel A), the discretionary accruals variables contribute significantly to the classification model only for the firms that committed fraudulent financial reporting. In a comparison of the type 0 vs. type 1 firms (those with weak internal controls), the model correctly classifies $78.9 \%$ of the firms. The significant variable in the model is net income / total assets (NITA), which is significantly lower for the firms with internal control weaknesses. The model that compares healthy firms to type 2 firms (those that committed fraudulent financial reporting) correctly classifies $82.4 \%$ of the total firms. The variables for total liabilities / total assets (TLTA), total accruals (ACCTA), and discretionary accruals (DAP) have significantly higher influence in classifying fraud firms. The variables for sales / total assets (SATA), and net income / total assets (NITA), are significantly lower for the fraud firms. When comparing the prediction model of healthy firms to type 3 firms (those firms that committed improper options reporting), the total classification accuracy is $86.8 \%$. The debt ratio of total liabilities / total assets (TLTA) is significantly lower for the fraud firms, and the liquidity ratio of current assets / total assets (CATA) is significantly higher for the fraud firms. 
Table 4. Panel A: logistic regression fraud detection model

\begin{tabular}{cccc}
\hline Variable & $\begin{array}{c}\text { Coefficient } ~ \\
\text { Type 0 v. Type 1 }\end{array}$ & $\begin{array}{c}\text { Coefficient } \\
\text { Type 0 v. Type 2 }\end{array}$ & $\begin{array}{c}\text { Coefficient - } \\
\text { Type 0 v. Type 3 }\end{array}$ \\
\hline Constant & -0.6395 & 0.4019 & 2.8648 \\
TLTA & 0.3205 & $3.6005^{*}$ & $-9.6132^{* * *}$ \\
CATA & 2.6600 & 4.1890 & $6.5145^{* *}$ \\
SATA & -0.4861 & $-1.6768^{* *}$ & -0.8681 \\
ACCTA & -2.6759 & $49.1311^{* * *}$ & -3.1251 \\
DAP & -1.7676 & $43.8627^{* * *}$ & -11.6343 \\
NITA & $-11.7687^{*}$ & $-44.2015^{* * *}$ & -2.8435 \\
\hline
\end{tabular}

Table 4: Panel A (continued): a comparison results of classifications using a fraud detection model

\begin{tabular}{lllll}
\hline & Type 0 (a) & Type 0 (a) & Type 0 (a) \\
v. & v. & v. & Type 3 (b) \\
Percent correct - & Type 1 (b) & $86.1 \%$ & Type 2 (b) & $91.7 \%$ \\
& Type (a) & $71.4 \%$ & $86.1 \%$ & $81.3 \%$ \\
\hline & Type (b) & $78.9 \%$ & $78.1 \%$ & $86.8 \%$ \\
\hline
\end{tabular}

In a comparison of the type 1 vs. type 2 firms (those with weak internal controls compared to those with financial statement fraud), the model correctly classifies $79 \%$ of the firms, as shown in Table 4, Panel B. The significant variables in the model are net income / total assets (NITA), which is significantly lower for the fraud firms; discretionary accruals $(D A P)$; and total accruals $(A C C T A)$, both of which are significantly higher for the fraud firms.

Table 4.Panel B: logistic regression fraud detection model

\begin{tabular}{cccc}
\hline Variable & $\begin{array}{c}\text { Coefficient } \\
\text { Type 1 v. Type 2 }\end{array}$ & $\begin{array}{c}\text { Coefficient } \\
\text { Type 1 v. Type 3 }\end{array}$ & $\begin{array}{c}\text { Coefficient }- \\
\text { Type 2 v. Type 3 }\end{array}$ \\
\hline Constant & $2.0421^{* *}$ & 1.7392 & -0.5406 \\
TLTA & 1.5159 & $-3.0777^{* *}$ & $-8.4152^{* * *}$ \\
CATA & -0.9863 & 0.3642 & 1.5019 \\
SATA & -0.8611 & -0.3887 & 0.4554 \\
ACCTA & $34.6392^{* * *}$ & 3.2237 & $-66.1336^{* * *}$ \\
DAP & $29.3615^{* * *}$ & 4.1779 & $-50.4353^{* * *}$ \\
NITA & $-29.6294^{* * *}$ & 1.2628 & $57.4560^{* * *}$ \\
\hline
\end{tabular}


Table 4. Panel B (continued): a comparison results of classifications using a fraud detection model

\begin{tabular}{lllll}
\hline & Type 1 (a) & Type 1 (a) & Type 2 (a) \\
& & v. & v. & v. \\
Percent correct - & Type 2 (b) & $77.1 \%$ & Type 3 (b) 3 (b) & $87.5 \%$ \\
& Type (a) & $81.3 \%$ & $74.3 \%$ & $87.5 \%$ \\
\hline & Type (b) & $79.1 \%$ & $68.8 \%$ & $87.5 \%$ \\
\hline
\end{tabular}

Description: Dependent variable is coded 1 for Type (a) company, 0 for Type (b) company. Used a cut-off score of .5 and above for Type (b) company. Type 1 = internal control weakness, Type 2 = financial reporting fraud, Type $3=$ options reporting fraud.

Note: $* * * \mathrm{p} \leq .01, * * \mathrm{p} \leq .05, * \mathrm{p} \leq .10$

A comparison of the type 1 vs. type 3 firms (those firms that had weak internal controls compared to those firms that committed fraud through improper options reporting) indicates a total classification accuracy of $71.6 \%$. These types of firms were not distinguished by the accruals variables, but by the debt ratio (TLTA), which was significantly lower for the type 3 firms.

Finally, when comparing the two types of fraud firms (type 2 vs. type 3), our model achieved a classification accuracy of $87.5 \%$. While the type 3 firms had significantly higher Net income to total assets (NITA), the type 2 firms showed a significantly higher influence of discretionary accruals $(D A P)$, total accruals $(A C C T A)$, and debt ratio (TLTA) in classifying fraud firms.

\section{Conclusions}

The results of our study indicate that healthy firms can be distinguished from firms with weak internal controls and from fraud firms, and in addition, the firms with these types of difficulties can be distinguished from each other when using discretionary accruals variables. This result is consistent whether the fraud is due to improper reporting of stock options or other financial statement fraud due to revenue misstatement or misappropriation of assets. This finding supports our first hypothesis. We also find that healthy firms, firms with internal control weaknesses, and firms with different categories of fraud can also be distinguished when using a fraud classification model with variables for total accruals and discretionary accruals, along with specific financial variables that assist in detecting fraud. This finding supports our second hypothesis.

Our study shows the importance of discretionary accruals variables in distinguishing between firms with internal control weaknesses as compared to healthy firms, and in identifying firms that commit various types of financial reporting fraud. We also contribute to the literature that has expanded the ability of auditors to assess fraud risk and examine restated earnings.

Being able to detect fraudulent financial statements is of value to investors. The healthy functioning of financial markets depends on truthful information about firm performance. As such, investors would expect to see more ethical behavior from the executives and directors of companies, especially after the implementation of Sarbanes-Oxley. The ability to detect fraud and manage risk has implications for individuals involved at all levels of corporate governance. Future research could examine whether specific aspects of corporate governance, such as structure and composition of the board of directors, are associated with the risk of financial reporting fraud.

\section{Acknowledgements}

This paper was previously presented at the Decision Sciences Institute 2009 Annual Meeting in New Orleans, L.A. The authors would like to thank the attendees and two anonymous reviewers for their helpful comments and suggestions. We would also like to acknowledge Dr. Pervaiz Alam and Dr. Michael Pearson for their assistance on an earlier version of this paper.

\section{References}

Aboody, D., \& Kasznik, R. (2000). CEO stock option awards and the timing of corporate voluntary disclosures. Journal of Accounting and Economics, 29, 73-100. http://dx.doi.org/10.1016/S0165-4101(00)00014-8

Argenti, J. (1976). Corporate Collapse: Causes and Symptoms. London: McGraw-Hill.

Ashbaugh-Skaife, H., Collins, D. W., Kinney, W. R., \& Jr., LaFond, R. (2008). The effect of SOX internal 
control deficiencies and the remediation on accrual quality. The Accounting Review, 83(1), 217-250. http://dx.doi.org/10.2308/accr.2008.83.1.217

Bartov, E., Givoly, D., \& Hayn, C. (2002). The rewards for meeting or beating earnings expectations. Journal of Accounting and Economics, 33, 172-204. http://dx.doi.org/10.1016/S0165-4101(02)00045-9

Bartov, E., \& Mohanram, P. (2004). Private information, earnings manipulations, and executive stock-option exercises. The Accounting Review, 79(4), 889-920. http://dx.doi.org/10.2308/accr.2004.79.4.889

Beck, R. (2003). Stock grants' motivation eyed. Tulsa World, p. E8.

Burgstahler, D., \& Dichev, I. (1997). Earnings management to avoid earnings decreases and losses. Journal of Accounting and Economics, 24, 99-126. http://dx.doi.org/10.1016/S0165-4101(97)00017-7

Cassidy, J. (2002). The greed cycle: How the financial system encouraged corporations to go crazy. The New Yorker, pp. 64.

Chan, K. C., Farrell, B. R., \& Lee, P. (2005). Earnings management and return-earnings association of firms reporting material internal control weaknesses under Section 404 of the Sarbanes-Oxley Act. Working paper.

Chen, C., \& Sennetti, J. T. (2005). Fraudulent financial reporting characteristics of the computer industry under a strategic-systems lens. Journal of Forensic Accounting, 6, 23-54.

Cohen, D., Dey, A., \& Lys, T. (2005). Trends in earnings management in the pre- and post- Sarbanes-Oxley periods. Working paper. http://dx.doi.org/10.2139/ssrn.658782

DeAngelo, L. E. (1986). Accounting numbers as market valuation substitutes: A study of management buyouts of public stockholders. The Accounting Review, 61(3), 400-420.

Doyle, J., Ge, W., \& McVay, S. (2007). Accruals quality and internal controls over financial reporting. The Accounting Review, 82(5), 1141-1170. http://dx.doi.org/10.2308/accr.2007.82.5.1141

Geiger, M. A., \& North, D. S. (2006). Does hiring a new CFO change things? An investigation of changes in discretionary accruals. The Accounting Review, 81(4), 781-809. http://dx.doi.org/10.1521/accr.2006.81.4.781

Graham, J. R., Harvey, C. R., \& Rajgopal, S. (2005). The economic implications of corporate financial reporting. Journal of Accounting and Economics, 40, 3-73. http://dx.doi.org/10.1016/j.jacceco.2005.01.002

Grove, H., \& Basilico, E. (2008). Fraudulent financial reporting detection: Key ratios plus corporate governance factors. International Studies of Management and Organization, 38(3), 10-42. http://dx.doi.org/10.2753/IMO0020-8825380301

Hansen, J. V., McDonald, J. B., \& Stice, J. D. (1992). Artificial intelligence and generalized qualitative-response models: An empirical test on two audit decision-making domains. Decision Sciences, 23(3), 708-723. http://dx.doi.org/10.1111/j.1540-5915.1992.tb00413.x

Iliev, P. (2007). The effect of SOX Section 404 management's report on audit fees, accruals and stock returns. Working paper.

Jones, J. (1991). Earnings management during import relief investigations. Journal of Accounting Research, 29(2), 193-228. http://dx.doi.org/10.2307/2491047

Jones, K., Krishnan, G. V., \& Melendrez, K. D. (2008). Do models of discretionary accruals detect actual cases of fraudulent and restated earnings? An empirical evaluation. Contemporary Accounting Research, 25(2), 6-30. http://dx.doi.org/10.1506/car.25.2.8

Kothari, S. P., Leone, A., \& Wasley, C. (2005). Performance matched discretionary accruals. Journal of Accounting and Economics, 39(1), 161-197. http://dx.doi.org/10.1016/j.jacceco.2004.11.002

Lai, K. W. (2003). The SOX act and auditor independence: Preliminary evidence from audit opinion and discretionary accruals. Working paper.

Lenard, M. J., \& Alam, P. (2004). The use of fuzzy logic and expert reasoning for knowledge management and discovery of financial reporting fraud. In Nemati, H., \& Barko, C. (Eds.), Organizational data mining: Leveraging enterprise data resources for optimal performance (pp. 230-262). Hershey, PA: Idea Group, Inc. http://dx.doi.org/10.4018/978-1-59140-134-6.ch016

Lenard, M. J., Watkins, A. L., \& Alam, P. (2007). Effective use of integrated decision making: An advanced 
technology model for evaluating fraud in service-based computer and technology firms. Journal of Emerging Technologies in Accounting ,4(1), 123-137. http://dx.doi.org/10.2308/jeta.2007.4.1.123

Liou, F. M. (2008). Fraudulent financial reporting detection and business failure prediction models: A comparison.Managerial Auditing Journal, 23(7), 650-662.http://dx.doi.org/10.1108/02686900810890625

Meek, G. K., Rao, R. P., \& Skousen, C. J. (2007). Evidence on factors affecting the relationship between CEO stock option compensation and earnings management. Review of Accounting and Finance, 6(3), 304-323. http://dx.doi.org/10.1108/14757700710778036

Persons, O. (1995). Using financial statement data to identify factors associated with fraudulent financial reporting. Journal of Applied Business Research, 11(3), 38-46.

Rosner, R. L. (2003). Earnings manipulation in failing firms. Contemporary Accounting Research, 20(2), 361408. http://dx.doi.org/10.1506/8EVN-9KRB-3AE4-EE81

Sarbanes Oxley Act (SOX). (2002). Public Law No. 107-204. Washington, D.C: Government Printing Office.

Summers, S. L., \& Sweeney, J. T. (1998). Fraudulently misstated financial statements and insider trading: An empirical analysis. The Accounting Review, 73(1), 131-146.

Tucker, J. W., \& Zarowin, P. A. (2006). Does income smoothing improve earnings informativeness? The Accounting Review, 81(1), 251-270. http://dx.doi.org/10.2308/accr.2006.81.1.251

\section{Copyrights}

Copyright for this article is retained by the author(s), with first publication rights granted to the journal.

This is an open-access article distributed under the terms and conditions of the Creative Commons Attribution license (http://creativecommons.org/licenses/by/3.0/). 